KATSAUS

\title{
MITEN TUTKIA KUMMIA KOKEMUKSIA?
}

\author{
Kaarina Koski ja Marja-Liisa Honkasalo
}

Uomen Akatemia myönsi vuonna 2013 rahoituksen ihmismieltä ja sen toisiin
todellisuuksiin suuntaavia kokemuksia tarkastelevalle Mieli ja toinen -tutkimus-
projektille. Projektille on kertynyt pääasiassa spontaaneina yhteydenottoina tois-
tasataa kirjettä käsittävä aineisto nykyajan epätavallisista kokemuksista. Näiden
kokemusten määrittely yliluonnollisiksi tai paranormaaleiksi ei tuntunut tekevän
oikeutta kohteelleen, joten olemme käyttäneet niistä termiä kumma. ${ }^{1}$

Kokemukset, joiden olemassaoloa länsimainen tieteellis-tekninen ajattelutapa ei tunnusta, yhtenevät monissa muissa kulttuureissa eri aikoina raportoitujen ja niissä kulttuurisesti legitiimien ilmiöiden kanssa. Kulttuurien tutkimisen alkutaipaleilta lähtien keskeisiä tutkimuskohteita ovat olleet tutkijan omasta tieteellistyvästä maailmankuvasta poikkeavat todellisuuden hahmottamisen tavat, rituaalit, käsitykset hengistä, jumalista ja vainajista sekä kontakteista niihin. Tutkimuskohteet on konstruoitu paljolti tutkijoiden oman arvomaailman ja kulttuuristen instituutioiden ehdoilla. Kun kulttuurien tutkijat ovat tarkastelleet toiseutta edustavia maalaisrahvaan ja ulkoeurooppalaisten kansojen traditioita, legitiimissä kristillisessä kehyksessä tapahtuneet elämykset ja visiot ja niiden tulkinnat ovat kuuluneet teologian ja historian alaan. Uskontotieteessä on tarkasteltu myös kristinuskoon kiinnittyvää uskonnollista kokemusta (Csordas 1994; ks. myös Hovi 2007, 36-43). Filosofian piirissä kumman ongelmaa osana mielen toimintaa ja todellisuuden mahdollisia alueita ovat pohtineet erityisesti William James (1981) sekä useat fenomenologit, kuten Henri Bergson (1963), Maurice Merleau-Ponty (1962), Jean-Paul Sartre (2004) ja Alfred Schutz (2007). Omassa nykykulttuurissamme legitiimin uskonnollisen kehyksen ulkopuolella tavattuja poikkeavia kokemuksia on sen sijaan tarkasteltu psykologian, lääketieteen ja psykiatrian näkökulmista. Tämän ohella kokemukset ovat kiinnostavia taiteen piirissä sekä taiteentutkimuksen ja useissa psykoanalyyttisen tutkimuksen keskusteluissa.

Tutkiaksemme aidosti näitä kokemuksia inmismielen ominaisuutena meidän on purettava aiempi työnjako. Kokemisella on aina ruumiillinen pohjansa, mutta samalla oma elämänhistoria, sosiaaliset suhteet ja kulttuurinen ympäristö muokkaavat yksilön kohtaloa ja kokemuksia. Tutkimushankkeessamme lähestymme

1 Kiitämme Mieli ja toinen -tutkijaryhmän sekä Kumma-tutkijaverkoston jäseniä keskusteluista, jotka ovat auttaneet tämän artikkelin laatimisessa. 
kysymyksiä tieteidenvälisesti. Tarkastelemme kummaa folkloristiikan, kulttuurihistorian, aatehistorian, antropologian, sukupuolentutkimuksen ja psykiatrian lähtökohdista tutkimusprosessissa siten, että annamme käyttämiemme käsitteiden ja teorioiden keskustella keskenään ja pyrimme luomaan yhteisiä metodologioita, jotka mahdollistavat monisäikeisten kysymysten avaamista.

\section{TERMINOLOGISIA ONGELMIA}

Arkitodellisuuteen kuulumattomista kokemuksista ja ilmiöistä puhutaan usein yliluonnollisina sekä tutkimuksessa että arkikielessä. Yleisesti tunnettuna ja paljon käytettynä termi yliluonnollinen on informatiivinen osoittaessaan, mille elämänalueelle kuuluvista asioista on kysymys. Emic-käsitteenä se on ristiriitainen. Osa kokijoista käyttää sitä itse. Toiset puolestaan kiistävät kokeneensa yliluonnollista ja pitävät kokemiaan ilmiöitä luonnollisina, joskin arkitodellisuudesta poikkeavina. Tieteellisenä käsitteenä yliluonnollinen sisältää oletuksen luonnollisen ja siihen kuulumattoman erottamisesta toisistaan. Taustana ovat tutkijoiden länsimaiset oletukset ensinnäkin siitä, että heillä itsellään on oikea tieto rajan paikasta. Historiallisessa katsannossa samoin kuin antropologian piirissä (esim. Tambiah 1990; Luhrmann 1989; Stark 2006) tosin voidaan todeta, että tieteen viimeisin sana siitä, mitä on olemassa ja mitä ei, on muuttunut monta kertaa. Toinen etnosentrinen oletus on, että ylipäätään on tärkeää tehdä kategorinen ero juuri luonnon ja siihen kuulumattoman välille. Kuten yliluonnollisen käsitettä kritisoineet tutkijat ovat huomauttaneet, luonnollisen käsite voi olla kulttuurissa myös täysin merkityksetön. (Saler 1977, 38-42; Aragon 2003; Greenfield 2003, 153-156; Sered 2003). Tärkeämmät kategorioinnit voivat perustua esimerkiksi oman ja vieraan väliseen rajaan.

Yliluonnollisen taustana oleva latinan kielen sana supernaturalis liittyy alkujaan kristilliseen pyrkimykseen erottaa toisistaan luonnollinen eli luotu ja sen lainalaisuudet ylittävä jumalallinen eli yliluonnollinen luoja. Jaon taustalla vaikuttivat uusplatonistiset ja gnostilaiset ajatukset henkisestä materiaalista parempana. (Oxford English Dictionary, s.v. supernatural; Saler 1977, 42-48.) 1600-luvulla tieteellinen kiinnostus alkoi kuitenkin kohdistua yhä voimakkaammin luojan sijasta luotuun todellisuuteen ja sitä ohjaaviin luonnonlakeihin. Esimerkiksi Thomas Hobbesin materialismin mukaan ei ole muuta kuin aineellinen todellisuus. (Garber 2008, 773-775; Milton 2008, 694-696.) Sen myötä tieteellisen ymmärryksen ulkopuolelle jäävät ilmiöt yhdistyivät joukoksi kyseenalaisia uskomuksia. Toden ja unen sekoittaminen keskenään ja taikausko julistettiin takapajuisten ja sivistymättömien inmisten ominaisuudeksi. (Hufford 2005, 25-26.) Yliluonnollisen määrittelystä olemattomaksi, harhaksi ja hallusinaatioksi on lyhyt matka kokijoiden leimaamiseen, ja sitä onkin luonnehdittu myös termin väärinkäytöksi (Hufford 1995, 15). Termin puolustajat korostavat kulttuurisesti vaihtelevaa jatkumoa luonnollisen ja siitä poikkeavan välillä sekä yliluonnolliseen suuntautuvien tietoista etäisyyden ottoa tieteellisestä ajattelusta (Walker 1995, 2-6). Näin yliluonnollinen voidaan kuvata hyväksyttävänä osana kulttuuria. Esimerkiksi Laura Stark kuvaa yliluonnollisen - tai maagisen - tiedon osaksi jatkuvaa arkista tietämystä esimodernissa suomalaisessa kyläyhteisössä (Stark 2014,143-144). Termin ongelmallisuus korostuu kuitenkin nykykulttuurissa, jossa ovat läsnä viittaukset harhoihin ja ristiriitaiset merkitykset. 
Paranormaali otettiin käyttöön 1920-luvulla uskonnollisesti neutraalina terminä korvaamaan kristinuskoon kiinnittynyttä yliluonnollisen käsitettä. Termin kehittänyt, Lontoossa vuonna 1882 perustettu Society for Psychical Research oli kiinnostunut ilmiöistä, jotka haastoivat sellaiset tieteelliset selitysmallit kuin telepatia, psykokineesi ja selvänäkijyys. (Gregory 2004; Lindeman \& Svedholm 2012, 2; "paranormal" teoksessa Colman 2009). Parapsykologiseen keskusteluun ja tutkimukseen osallistui myös pragmatistifilosofi William James (1986). Hän suoritti tutkimuksia muun muassa meedioiden parissa. Tutkimuksellisena terminä paranormaali määrittelee ilmiön normaalin ulkopuolelle tai normaalin vastaiseksi (kreikk. para). (Lindeman \& Svedholm 2012, 1; Etymology online). Normaali viittaa paitsi tyypilliseen ja tavanomaiseen myös normin olemassaoloon. Se, mikä on normaalin ulkopuolella tai sille vastakkaista, voi olla myös epänormaalia. Paranormaalin suhde epänormaaliin näkyy muun muassa siinä, miten arkitodellisuuteen kuulumattomia kokemuksia patologisoidaan lääketieteessä. Tämä tekee termistä eettisesti ongelmallisen.

Suomalaisessa kansanuskon tutkimuksessa on käytetty tuonpuoleisen käsitettä merkitsemään ihmisten arkitodellisuuteen kuulumattomia elementtejä, joiden ominaisuuksia voivat olla vieraus, myyttisyys tai erityinen vaikuttava voima (esim. Apo 1995; Koski 2011, 77-78; Siikala 1992; Tarkka 2005). Vanhan kansanuskon maailmankuvassa arkitodellisuuteen kuulumaton käsittää sekä "näkymättömän" maailman että sellaiset näkyvät todellisuudet, jotka eivät ole yhteisön hallinnassa ja heidän sosiaalisen säännöstönsä piirissä. Näin määriteltynä tuonpuoleisen käsite noudattaa tutkittavan kulttuurin omia jäsennyksiä. Tuonpuoleinen voi toimia folkloressa myös metaforisena kuvana, jonka kautta yhteisön identiteettiä muovataan. (Tarkka 2005, 328.) Nykykulttuurin käsityksiä tuonpuoleinen ei kuitenkaan kuvaa yhtä osuvasti. Termin yksiselitteistä käyttöä hankaloittaa myös sen kuolemanjälkeiseen viittaava merkitys emic-käsitteenä.

Yliluonnollista on pyritty korvaamaan myös kognitiiviseen tutkimukseen pohjautuvalla intuitionvastaisen käsitteellä. Tutkijat ovat esittäneet inmisten erottavan intuitiivisesti toisistaan fysikaaliset, biologiset ja mentaaliset oliot ja liittävän niihin automaattisesti kategorian mukaisia odotuksia. Intuitionvastaisia ovat oliot ja ilmiöt, jotka poikkeavat näistä odotuksista, kuten emootioita osoittavat patsaat tai ruumiittomat toimijat. (Esim. Boyer 1994, 34-35; Pyysiäinen 2008, 31-39.) Pascal Boyerin $(1994 ;$ 2001) mallissa intuitiivisilla odotuksilla tarkoitetaan jokseenkin arkijärkeä, jolloin ruumiiton mentaalinen toimija luokitellaan intuitionvastaiseksi. Käsitettä on kritisoitu siitä, että se olettaa ihmisten pitävän universaalisti intuitiivisina tutkijoiden omaan arkikokemukseen pohjautuvaa järjestystä (esim. Rydving 2008, 80-81). Intuitionvastaisen käsite oikeastaan merkitseekin ei-reflektiivisen arkiajattelun vastaista (Alles 2008, 329). Jos intuition määrittelee Dan Sperberin $(1996,89)$ tapaan spontaaniksi ja tiedostamattomaksi havaitsemiseksi ja päättelyksi, esimerkiksi animistisen ajattelun voi katsoa olevan nimenomaan intuitiivista (Guthrie 2002). Ajatus mentaalisesta toimijasta ilman fyysistä ruumista voi kokeellisten tutkimusten mukaan myös olla intuitiivinen (esim. Barrett 2008, 321). Psykologiassa intuitio viittaa myötäsyntyisiin kognitiivisiin ominaisuuksiin. Psykologit lähestyvät intuitiivisina vinoumina (intuitive biases) samoja uskomuksia ja mielikuvia, joita kognitiivinen uskontotiede nimittää intuitionvastaisiksi. Sellaisiin 
kuuluvat esimerkiksi animismi, ruumiin ja sielun erillisyys toisistaan sekä taipumus mieltää satunnaiset tapahtumat merkityksellisiksi ja intentionaalisiksi. (Svedholm 2013, 22-25.) Intuitio voidaan myös yhdistää taiteelliseen ajatteluun sekä luovuuteen ja innovatiivisuuteen, jolloin se ei ole tietoisen järkeilyn puutetta vaan harjoittamisen arvoinen mielen ominaisuus (Raami 2013; Outinen 2014). Henkilökohtaisten kummien kokemusten kuvaukset viittaavat siihen, että aistimusten tai tuntemusten tulkinta vainajan vierailuksi tai merkitykselliseksi enteeksi on usein nimenomaan intuitiivinen tulkinta. Näiden kokemusten nimittäminen intuitionvastaisiksi olisi paradoksaalista.

Näin ollen lähestymme tutkimiamme kokemuksia kummina. Kumma viittaa kokemuksiin ja ilmiöihin, jotka ovat arkikokemuksesta poikkeavia ja jotka viittaavat toisiin todellisuuksiin, selittämättömiin ilmiöihin tai erikoisia mentaalisia ilmiöitä hyödyntäviin syy- ja seuraussuhteisiin. Termi ei ota kantaa näiden ilmiöiden ontologiaan vaan niiden asemaan toisaalta kokijoiden itsensä, toisaalta valtakulttuurin maailmankuvassa. Vaikka kokijat itse alkaisivat pitää esimerkiksi toistuvaa ennalta tietämistä tavallisena, he tietävät, että muut inmiset voivat kummeksua sitä. Kumma jättää myös tilaa kokijoiden tulkinnoille. Monet käyttävät itse esimerkiksi henkimaailman käsitettä, mutta se on vain yksi selitys kummalle eikä vastaa kaikkien näkemystä.

\section{KOKEMUS JA TRADITIO}

Folkloristiikassa on tutkittu jo parin vuosisadan ajan kansanomaisia uskomustraditioita. Antropologian piirissä uskomusten ohella myös ihmisten kokemukset kummasta ovat olleet tärkeitä tutkimuskohteita. Kokemuksen sijaan folkloristinen intressi on kohdistunut tyypillisemmin ilmaisutraditioihin sekä kollektiivisiin uskomuksiin ja maailmankuviin. Tutkijoiden omista poikkeavat kokemisen tavat on voitu sivuuttaa kansanuskoon tai "kansan" perustavalaatuiseen toiseuteen kuuluvina.

1930-luvulla pohjoismaisessa folkloristiikassa virisi niin sanottu perinnepsykologinen kiinnostus, joka pyrki selvittämään haltijaelämysten syntyä havaintopsykologian pohjalta. Havainnossa kokija täydentää aistiärsykkeen senhetkisen tulkintakehyksensä ja odotustensa mukaiseksi (Granberg 1935; Haavio 1942). Lauri Honko painotti erityisesti tradition luomien odotusten merkitystä elämysten synnyssä sekä sellaisia sosiaalisia rooleja, joissa esimerkiksi haltijan kohtaamiseen oli perinteenmukaisia perusteita. (Honko 1962.) Elämyksille altistaviksi tekijöiksi listattiin myös havaintoa ja mentaalista suorituskykyä muuttavat tekijät kuten stressi, humala ja väsymys (Haavio 1942, 74-80; Honko 1962, 106-107). Hongon näkemystä elämyksistä uskomusperinteen synnyttäminä on sanottu kulttuurihypoteesiksi. David Huffordin esittämän elämyshypoteesin mukaan yliluonnollisia elämyksiä kuitenkin syntyy myös ilman niitä tukevan uskomusjärjestelmän tuntemusta. Käytännössä nämä näkemykset eivät kumoa vaan täydentävät toisiaan. (Hufford 1982; ks. myös Enges 2004.) Kulttuuriset tekijät vaikuttavat kokemuksiin, mutta ihmisillä on myös elämyksiä, jotka eivät perustu heidän ontologisiin käsityksiinsä.

Akateeminen maailma piti pitkään yllä illuusiota siitä, että modernisaation myötä kansanomaiset uskomusperinteet ja yliluonnolliset elämykset ovat hävinneet. 
Niiden jäänteitä katsottiin esiintyvän länsimaissa enää menneisyyttä tai vierautta edustavien marginaaliryhmien tai mieleltään järkkyneiden parissa. Niin ei kuitenkaan ole. (Hufford 2005, 26-27.) Suomessa modernin ihmisen yliluonnollisia kokemuksia tutki jo 1970-luvulla Leea Virtanen. Ymmärtävä suhtautuminen yliluonnollisiin kokemuksiin ei tuolloin saanut tiedeyhteisön ehdotonta hyväksyntää. Virtasen työtä kritisoitiin myös siitä, että hän nojasi oman oppialansa traditioiden sijaan psykologiseen ja parapsykologiseen kirjallisuuteen, johon hän ei kohdistanut erityisen terävää lähdekritiikkiä. Tiedeyhteisön ensimmäisenä reaktiona oli vaieta jokseenkin kuoliaaksi hänen vuonna 1974 ilmestynyt teoksensa Kun kello pysähtyi. (Enges 2004.)

Julkaisunsa "That Must Have Been ESP!" esipuheessa Virtanen totesi tuloksenaan, etteivät elämykset ole sidoksissa uskomusperinteen tuntemukseen: kirjoittajat olivat raportoineet samankaltaisia ilmiöitä tuntematta sellaiseen liittyvää traditiota tai toistensa lausuntoja. Aineistojen äärellä ainoa järkevä ratkaisu oli uskoa kuvauksiin ja pitää mieli avoimena niiden kaikille mahdollisille selityksille. Kulttuurisidonnaisuuden sijaan tulokset viittasivat ilmiöihin, jotka voisivat muuttaa ymmärryksemme inmisyydestä. Tällä Virtanen viittasi mahdollisuuteen, että telepatia ja ennaltatietäminen ovat inmismielen ominaisuuksia. (Virtanen 1990, xvi-xvii, 7-8.) Lukuun ottamatta Virtasen toivetta paranormaalien ilmiöiden todistamisesta mittalaittein hänen viitoittamaansa tietä voidaan seurata ja suhtautua vakavasti kokijoiden kertomuksiin. Fysikaalisen todellisuuden sijaan tutkijaryhmämme hakee lisätietoa mielen ja sen toimintojen kautta.

\section{OPPIHISTORIAA: TOISEUS SELITTÄÄ KAIKEN}

Valtaosa varhaisimmista kansanomaisten uskontokulttuurien tutkijoista katsoi tarkastelevansa inmisiä, joiden kulttuuri tai mentaalinen kapasiteetti oli alemmalla tasolla kuin heidän omansa. Suomessa rahvaan katsottiin vielä 1900-luvun alkupuolella olevan olennaisesti erilaista kuin sivistyneistön, ja heistä rakennettiin aktiivisesti kuvaa, joka tuki nuoren kansakunnan itsemäärittelyä (Apo 1998). Tutkimuksessa eksotisoitiin runonlaulajia ja tietäjiä, joiden tietojen ja uskomusten katsottiin edustavan kansallista menneisyyttä (Tarkka 1989). Modernisoituvalle lännelle ei-modernit yhteisöt olivat myös vertailukohta, josta peilattiin omaa kehitystä ja samalla määriteltiin enemmän tai vähemmän tietoisesti oikeanlaista inmisyyttä tai uskontoelämää. Varhaisen antropologian klassikoista James Frazerin ja E.B. Tylorin evolutionistisissa kehityskaarissa magiasta uskontoon ja tieteeseen on myös nähty uskonnollis-poliittinen argumentti protestanttisen uskon puolesta maagiseksi moitittua katolisuutta vastaan (Tambiah 1990, 18-19, 44-54).

1900-luvun kuluessa antropologiassa tehtiin selväksi, ettei kulttuurien ja rotujen välillä ole eroja mentaalisessa kapasiteetissa. Lucien Lévy-Bruhl, jonka nimiin jäi arvio primitiivisen inmisen esiloogisuudesta, selitti mystisen partisipaation käsitteellä asennetta, jolla ympäröivää maailmaa jäsennetään varhaiskantaisissa kulttuureissa empatian ja kollektiivisuuden pohjalta eikä kausaalisesti kuten länsimaissa. Postuumisti 1949 julkaistuissa teksteissään hän painotti, että molemmat ajattelun moodit löytyvät kaikista kulttuureista. (Tambiah 1990, 84-87.) Kun ero ei ollut mentaalinen vaan pohjautui kulttuurisiin arvoihin, varhaiskantaisista 
maailmankuvista löydettiin myös esikuvallisuutta. Teoksessaan The Mind of Primitive Man Franz Boas arvosteli länsimaista järkeilevää ajattelutapaa ja tunne-elämän tukahduttamista. Vain taiteilijoilta ja uskonnollisilta yksilöiltä löytyi avoin asenne valtavirrasta poikkeavia mielen- ja tunnetiloja kohtaan. (Boas 1955 [1938], 143, 227.) Primitiivisten maailmankuvien on arveltu pääsevän monessa kohtaa jopa länsimaisia maailmankuvia lähemmäs totuutta: moderni tiede ei välttämättä vain laajenna vaan myös rajoittaa ajatteluamme (van Baaren 1972, 23).

Antropologiassa toiseutta on kyseenalaistettu myöhemmin metodin, erityisesti tutkijaposition avulla. Victor Turner (1967) tutki pitkäkestoisissa kenttätöissään ndembujen rituaalien merkitystä yhteisön, yksilön sekä rituaalissa rakentuvan siteen kannalta. Hänen teoriansa liminaalisuudesta korosti rituaalin merkitystä elämän ja yhteisön murroskohdissa. Liminaalissa meidän kummaksi kutsumamme, magian ja luovuuden rajat näyttäytyivät liukuvina. Uudenlainen näkökulma toiseuden taltuttamiseen syntyi postmodernin perinteen puitteissa. Ranskalainen antropologi Jeanne Favret-Saada suhtautui kriittisesti psykiatrisiin teorioihin, joiden välityksellä noituudesta pyrittiin tekemään hulluutta ja ihmisiä leimattiin. Hän tutki noituutta ranskalaisessa maalaiskylässä oman noidutuksi tulemisensa avulla ja tavoitti kokemuksen kumman alueen yhdessä informanttiensa kanssa. (Favret-Saada 1980.) Rajaa toiseuteen pyrittiin häivyttämään myös Tanya Luhrmannin etnografiassa Persuations on the Witch's Craft. Luhrmann osallistui Lontoon alueella useita eri yhteiskuntaryhmiä edustavien ihmisten toimiin noituuden parissa. Hän kiinnitti työssään huomiota englanninkielisen sanan witchcraft puoleen craft, johon paljastui sisältyvän noituuskäytännöissä mitä moninaisimpia vakuuttamisen, hurmaamisen ja vaikuttamisen kykyjä ja taitoja. (Luhrmann 1989.) Etnografisissa töissään Michael Taussig $(1980 ; 1993)$ on tutkinut vastaavia käytäntöjä shamaanien toimittamissa rituaalisissa hoitotilanteissa. Taussig laajentaa toiseuden ongelman koskemaan länsimaista kulttuuria ja sen keskeistä käsitystä totuuden ja representaation luonteesta. Hän korostaa toiseuden tutkimusta tärkeänä ikkunana ja välineenä antropologiseen omaan länsimaiseen kulttuuriin kohdistuvaan kulttuurikritiikkiin. Susan Greenwoodin (2000; 2005) tutkimus nykypäivän länsimaisesta magiasta puolestaan tarkentaa hypoteesiin tietoisuuden monimuotoisuudesta. Greenwood viittaa maagisen tietoisuuden käsitteellä tiedostamisen laajempaan muotoon, joka on hänen mukaansa ihmistajunnalle ominainen.

Kummien ilmiöiden tulkitseminen kulttuurisessa kehyksessään on lähtenyt usein siitä, että kulttuurinen ympäristö ja maailmankuva, johon yksilö kasvaa, ohjaavat kokemisen ja tulkinnan tapoja. Vaikka näin onkin, tutkijoiden ei tule selittää ongelmallisia ilmiöitä toiseudella vaan suhtautua niihin avoimesti. Toiseuden purkaminen tuo mahdollisuuden kulttuurin ja ihmismielen aidompaan ymmärtämiseen.

\section{RUUMIILLINEN KOKIJA}

Kummat kokemukset ovat askarruttaneet pitkään humanistista tutkimusta myös filosofian, taiteentutkimuksen ja psykoanalyysin teorian alueella. Freud viittaa esseessään "Unheimlich" kokemukseen, jossa tuttu ja turvallinen (heimlich) muuttuu yhtäkkiä kammottavaksi. Freudin mukaan kokemus muuttuu eksymisen, kaksoisolennon kokemisen tai kummituskokemusten myötä merkittäväksi minän 
rajojen kannalta. (Freud 1981 [1919].) Freudin näkemys pohjautui kansankertomuksiin, kirjallisuuteen (Sarjala 2014), psykoanalyyttiseen potilastyöhön ja omiin kokemuksiin. Teoreettisena päämääränä oli palauttaa unheimlich mielensisäiseksi tapahtumaksi, joka ei uhkaa käsitystä todellisuuden luonteesta. Myöhemmin Julia Kristevan (1980) abjektin teoria on virittänyt keskustelua kammottavasta ja sen kokemiseen liittyvästä ambivalenssista, kammottavan ja houkuttelevan yhteenkietoutumisesta.

Unheimlich tai abjekti virittää kysymyksen kokemuksen ruumiillisuudesta. Ruumiinfenomenologisen ajattelun mukaan kokemus omasta ruumiista ei ole kokemus vieraasta tai objektista vaan se on muotoa "olen ruumiini". Siten oma ruumis käsitetään subjektina, joka on kokemuksen ja tiedon lähde (Merleau-Ponty 1962). Ruumiillinen kokemus on välitön ja eletty, eikä se ruumiinfenomenologisen ajattelun mukaan edellytä representaatiota. Merleau-Pontyn kuuluisa esimerkki on aaveraajakokemus, jossa puuttuva raaja ja sen kokema kipu ovat edelleen osa ihmisen ruumiinskeemaa ja hänen situaatiotaan maailmassa. Eletty kokemus omasta ruumiista havainnollistuu myös kosketuksessa, jossa oikea käsi koskettaa vasenta. Käsi on samalla sekä koskeva että kosketettava, subjekti ja objekti.

Ruumiillisena olemisen lähtökohtainen vieraus on askarruttanut länsimaisia ajattelijoita monesta näkökulmasta. Vieraantuminen on paitsi yhteiskunnallista myös mielensisäistä, kuten Freud ilmaisee, tai eksistentiaalista (Sartre 2004). Tätä taustaa vasten vieraus ja kumma voidaan ymmärtää joksikin alun alkaen ihmiseen kuuluvaksi. Pisimmälle ajatuksen on kehittänyt Bernard Waldenfels, jonka mukaan kokemus on kahtiajakautunut, ja toiseus tai vieraus on eräänlainen murtumalinja (Bruchlinie) kokemuksen rakenteessa (Waldenfels 2001, 91). Kokemus toisesta on ikään kuin vastaan-käymistä. Vieraus vastaanotetaan kokemuksessa, jolloin vieraus ja toiseus ovat toistaan koskettavia ja kuuluvat kokemukseen sen rakenteellisena piirteenä (Waldenfels 2011, 55).

1990-luvun alusta jatkunut vireä keskustelu ruumiillisuudesta kulttuurintutkimuksen ja yhteiskuntatieteen piirissä on painottanut eletyn kokemuksen tutkimusta yhtenä metodologisena mahdollisuutena jäsentää alojen keskeisiä ja mentaaliseen tai rationaaliseen taipuvia olettamuksia (Turner 1991). Thomas Csordas (1990; 1994) on tutkinut uskonnollista kokemusta ja parantamista. Hän hahmottaa työssään eletyn ja välittömyyden merkitystä korostamalla, miten kulttuuri kertyy kokemukseen kulttuuristen käytäntöjen kautta. Kokemus on esi-objektiivista ja sellaisena kulttuurista ja samalla elettyä: jotain, mikä on olemassa ruumiillisuudessa aistimusten ja suuntautumisen tasolla. Kertyminen toteutuu ruumiin liikkeessä sekä aistimuksissa ja suhteessa toisiin. Monet tutkijat kirjoittavat toistosta ja habituaalisuudesta (Berger ja Luckmann 1994, Bourdieu 1990). Niiden kautta kertyminen toistuu, ja toistumisen kautta kulttuuri kerrostuu (embodied) ruumiillisuuteen. Eletyn kokemuksen kautta ruumiista tulee kulttuurinen. Tutkimuksessaan inmeen kokemuksesta modernissa yhteiskunnassa Jon Mitchell (2008) soveltaa eletyn ruumiillisuuden lähestymistapaa ja tarkastelee kertymistä toistuvissa rituaalisissa käytännöissä. Hänen mukaansa ihmeidenkin kokeminen on mahdollista oppia yhteisöllisesti näiden käytäntöjen puitteissa. Kokemus on tutkittavissa elettynä esimerkiksi ruumiin liikkeiden, eleiden tai ilmeiden välityksellä. Ihmisillä on tapana luoda 
kulttuuria ikään kuin toisena luontona, matkimisen ja toistamisen keinoin (Taussig 1993, 129). Fenomenologi Kay Toombs (1992) on tutkinut elettyä tilaa: hänen tutkimuksessaan tilan ja sairaan välinen suhde jäsentyy erityisellä tavalla sairauden pitkäkestoisuudesta ja vakavuudesta riippuen (ks. myös Honkasalo 1998). Aika tai tila eivät ole objektiivisia tai abstrakteja vaan rakentuvat kokemuksen kautta.

Ruumiinfenomenologia on ollut yhtenä taustatekijänä toimijaverkkoteoriaan pohjautuvassa ontografisessa lähestymistavassa, josta on tullut uusi avaus kulttuurintutkimukseen (Latour 2005; Holbraad ym. 2007;). Ontografinen metodi lähestyy tekijää ja toimijuutta verkostomaisena ja useiden toimijoiden kesken jakautuneena. Esimeriksi uusmaterialistisessa uskontotieteellisessä tutkimuksessa toimijoina voidaan nähdä myös esineet (Miller 2001) tai eläimet. Nämä ajatukset jäsentävät kiinnostavalla tavalla aineistomme kertomuksia kummasta. Kummalla voi olla tärkeä rooli yksilön toimijaverkostossa tai se voi johtaa verkostojen muutokseen. Ontografisessa kirjallisuudessa toimijalla on liikkeellepaneva rooli. Kumman toimijan aikaansaama liike, ääni tai toiminta - joskus kovaääninen mutta joskus vain hipaisu - voi olla kokijan elämässä merkityksellinen.

\section{KUMMIEN KOKEMUSTEN LAAJA SKAALA}

Uskonnollisen kokemuksen tutkimisen uranuurtaja William James esitti 1900luvun alussa, että ymmärtääksemme kokemusta meidän on tutkittava myös sen äärimuotoja. Hän pyrki tarkastelemaan uskonnollisten elämysten koko skaalaa arkisista hyvin rajuihin ja poikkeuksellisiin kokemuksiin. (James 1981.) Meidänkin aineistossamme kuvaukset muodostavat laajan skaalan paitsi tulkintojensa, myös elämyksen fyysisen intensiivisyyden sekä toistuvuuden osalta. Ne ulottuvat ruumiista irtautumisesta, kuolemanrajakokemuksesta ja esineiden liikkumisesta ennalta tietämiseen, eri aistein koettuihin vainajien ja henkiolentojen kohtaamisiin sekä uniin. Ne vaihtelevat myös yksittäisistä kokemuksista usein toistuviin sekä pysyvään kykyyn kokea ilmiöitä, joita muut eivät havaitse.

Tärkeitä eroja on myös sen suhteen, onko pääpaino kokemuksessa vai tulkinnassa. Kokijoilla voi olla yllättäviä, voimakkaan ruumiillisia ja tunteita herättäviä aistimuksia, joiden outous vaatii selitystä. Toiset taas nimenomaan odottavat sovittua merkkiä vainajalta tai pohtivat erityistä moraalista ongelmaa. Silloin esimerkiksi sinänsä arkinen tapaus kuten kynttilän liekin syttyminen tai sammuminen tai sähkölaitteiden käynnistyminen juuri tietyllä hetkellä voidaan tulkita merkiksi henkimaailmasta. Näissä tapauksissa kumma syntyy itse kokemuksen sijaan tulkinnassa ja mielekkäiksi koetuissa syy- ja seuraussuhteissa. Aineistomme sisältää siis sekä odotusten mukaisia että odottamattomia kokemuksia.

Etenkin jos kummiksi mielletyt kokemukset tai kyvyt ovat toistuvia ja pysyviä, niihin on totuttava tavalla tai toisella ja integroitava ne osaksi maailmankuvaa ja identiteettiä. Sen ohella, että kertomukset kummallisista kokemuksista kuvaavat inmisten kokemaa todellisuutta ja tulkintakehyksiä, ne myös muuttavat ja muovaavat maailmaa kertojien ympärillä (Stark 2006, 30). Kuullusta muovautuu toistuessaan aineksia käytäntöihin ja taitoihin, joita on mahdollisuus jakaa muiden kanssa. Ne voivat jälleen muokata kokemusta ja inmisten tietoisuutta outojen asioiden 
merkityksestä (Mitchell 2008). Yksi tie toistuvien kokemusten kanssa elämiseen on hankkia lisätietoa ja harjoitusta ja omaksua valtavirrasta poikkeava maailmankuva, johon yhteys henkimaailmaan kuuluu luontevasti. Tällaisilla inmisillä kokemukset eivät rajoitu oman elämän piirissä tapahtuviin ilmiöihin, vaan he toimivat esimerkiksi meedioina tai selvänäkijöinä. Kaikki eivät kuitenkaan tulkitse kokemuksia henkimaailmaan liittyviksi. Erikoiset näyt ja kokemukset voi myös tulkita luovuuden lähteeksi ja käyttää niitä taiteellisen työskentelyn pohjana. Myös tämä vaihtoehto edellyttää taipumuksen hallitsemista ja kykyä kanavoida se hedelmällisesti. Esimerkiksi teatterityössä hyödynnetään luovaa, intuitiivista tilaa, jonka hallitseminen on harjoituksen tuloksena syntyvää ammattitaitoa (Outinen 2014).

Kokemukset ja kyvyt voivat olla myös vaikeasti hallittavia, ahdistavia ja pelottavia. Pelkoa voi hälventää kokemusten integrointi uskomusjärjestelmään, johon sisältyy myös lohdullisia ja suojelevia elementtejä. Aina tilanne ei silti ole kulttuurisesti hallittavissa. Osa kokijoista saa mielenterveysdiagnoosin ja lääkityksen. Vaikka kummat kokemukset eivät sinänsä ole psykiatriassa merkki mielenterveyden häiriöstä, jos ne esiintyvät yksittäin, on totta, että hallusinaatioita esiintyy merkittävästi esimerkiksi skitsofrenian yhteydessä. Tämä on omiaan stigmatisoimaan muutkin, joilla on epätavallisia elämyksiä (Goffman 1963; Korkeila ym. 2011). Kokijat ovat tietoisia valtaväestön ennakkoluuloista epätavallisia henkisiä kykyjä ja näkyjä kohtaan. Kokemus voi siksi olla myös stigman sisäistämisen aiheuttaman identiteettikriisin paikka: kuulunko minä nyt niihin kummiin ihmisiin?

Aineistossamme kummat kokemukset ovat tulleet pääasiassa pyytämättä ja odottamatta. Samaan aikaan länsimaissa vaikuttaa henkisen kasvun ja henkisten kokemusten etsimisen trendi. Henkimaailmaan otetaan aktiivisesti kontaktia esimerkiksi šamanistisissa rumpupiireissä ja enkelikursseilla. Ihmiset opettelevat hyödyntämään energioita, etsivät elimistöstään chakroja ja saattavat pitäytyä spirituaalisin perustein valikoidussa dieetissä. Nykyajan henkisyydelle on ominaista keskittyminen omaan kokemukseen, hyvinvointiin ja henkiseen kasvuun. New age -pohjaisiin sosiaalisiin liikkeisiin kuuluu myös ajatus universaalista energiasta, jonka kautta yksilö voi kehittyä tai täydentyä. (Partridge 2005, 71-72; Tucker 2002.) Mukaan voivat kuulua myös erilaiset yksilön omia voimavaroja hyödyntävät meditatiiviset tekniikat. Tämä on omassa länsimaisessa kulttuurissamme se alue, jolla luonnollisen ja yliluonnollisen välinen raja menettää relevanssinsa. Kun mittatikkuna on oma kokemus, kaikki koettu on totta. Kun ympärillä on samanmielisten yhteisö, henkimaailma ei ole myöskään kumma.

\section{KOKEMUS, TULKINTA JA KERRONTA}

William James on tarkastellut mystisiä kokemuksia syvemmän tietämisen tiloina, jotka menevät pian ohi mutta jättävät merkittävän muiston. Yksi niiden olennainen piirre on, että sanat eivät tee kokemukselle oikeutta. Kertominen ei voi välittää käsitystä siitä toiselle inmiselle. (James 1981, 278-279.) Kaikki kummat kokemukset eivät ole mystisiä, mutta moniin niistä sisältyy tuntemuksia tai tunnereaktioita, joiden kuvaaminen voi olla vaikeaa. Kertominen ja kirjoittaminen ovat varsin länsimaisia käytäntöjä. Antropologisen tutkimuksen piirissä varoitetaan nojautumisesta tulkinnassa yksinomaisesti niihin, koska tämä sisältää reduktionismin vaaran 
(Taussig 1993; Stoller 1989). Kokemuksen voi esittää, kuten näyttämötaiteessa tehdään (Outinen 2014) tai kuten sairastunut voi tehdä rituaalisen parantamisen yhteydessä (Turner 1967). Voidaan myös tutkia tapahtumia ja seurauksia, joita kumma mahdollisesti saa aikaan kuten toimijaverkkoteoriassa (Latour 2005).

Tutkijoina olemme usein sen varassa, kuinka kokijan onnistuu kuvailla tuntemuksiaan ja aistimiaan ilmiöitä. Tässä, kuten yleensäkin, aineistona ovat kokijoiden kirjoittamat kielelliset kuvaukset ja kertomukset tapahtumasta. Kuvaamista ohjaavat kulttuuriset käsitteet ja tarjolla oleva sanasto. Esimerkiksi aistijärjestelmämme on kulttuurisesti määritelty ja nimetty. Sen varassa sisäiset aistit, emootiot ja muut kehollisen havaitsemisen ja tuntemisen tavat ovat vaikeasti verbalisoitavia. (Howes 2009, 2-5; Stoller 1989.) Kokemusten tutkiminen kertomusten kautta kertoo siis itse kokemusten ohella paljon myös siitä, millaisina kokemuksia on mahdollista verbalisoida ja kommunikoida muille.

Kertoja tulkitsee kokemaansa antaessaan sille henkilökohtaisia merkityksiä ja kiinnittäessään sen osaksi omaa elämäänsä. Hän esittää sen osana tapahtumaketjuja ja sosiaalisia tilanteita, joiden seikkaperäinen kuvaaminen on samalla kuulijan tai lukijan vakuuttamista. (Bennett 1986, 427-428.) Kerronta on aina myös suunnattu kuulijoille tai lukijoille ja muuntaa sisältöään ja muotoaan riippuen kertojan tavoitteesta sekä kuulijoiden reaktioista. Näihin luetaan sekä välittömät että odotettavissa olevat reaktiot. Henkilö, joka kertoo kummista kokemuksistaan julkisesti henkimaailmaan viittaavassa kehyksessä, on tietoinen niistä vastalauseista, joita voi olla odotettavissa, ja vastaa niihin jo etukäteen. (Bennett 1999, 117-118, 125.)

Mieli ja toinen -kirjeaineistossa näkyy oman normaaliuden ja kriittisen asenteen vakuuttaminen. Sen sijaan julkisempiin kerrontatilanteisiin liittyvää perinteenmukaistamista ei juuri esiinny. Kirjoittajat eivät esimerkiksi liitä kollektiiviselle traditiolle tyypillisiä moraalisia painotuksia kokemusten tulkintoihin. Kerronnan analyyttinen tarkastelu on yhtäältä lähdekritiikkiä, ja toisaalta se antaa tärkeää lisätietoa kuvattujen kokemusten asemasta kertojan sosiaalisessa todellisuudessa. Kokemuksen tutkiminen kertomusaineiston pohjalta edellyttää tutkijoilta kuitenkin myös valmiuksia ymmärtää ihmismielen toimintaa.

\section{MIELI JA TOINEN -KIRJEAINEISTON PIIRTEITÄ}

Henkiset liikkeet toisaalta haastavat, toisaalta sivuuttavat tieteellisen tiedon tietämisen tapana. Tiede, joka sivuuttaa henkilökohtaisen kokemuksen, ei yleensä ole ensisijainen keskustelukumppani niitä pohdittaessa. Mieli ja toinen -hankkeelle kertyneen kirjeaineiston erityinen ominaisuus on kuitenkin se, että kirjoittajat ovat aktiivisesti ottaneet yhteyttä akateemiseen tutkimushankkeeseen. He toivovat tieteeltä vastausta hankaliin ontologisiin kysymyksiin. Osalla yhteyttä ottaneista on pitkä kokemus henkimaailmasta tai toisista todellisuuksista. Heidän kohdallaan korostuu halu edesauttaa tieteellisen tiedon kehittämistä tästä alueesta.

Kirjoittaminen on ollut myös mahdollisuus tulla kuulluksi ja todistaa kiistellyn asiaintilan puolesta. Vastaavaa todistusluonnetta on poliittisesti kiistanalaisiin tapahtumiin liittyvissä elämäntarinoissa, jotka todistavat vaietuista kohtaloista. Ne puhuvat 
sekä oman kokemuksen että muiden vastaavaa kokeneiden puolesta ja haastavat aiemmin esitetyn version totuudesta. (Skultans 2001, 766.) Kumman äärellä todistamisen tarve syntyy, kun oma kokemusmaailma ja sosiaalisesti hyväksytyt tulkintakehykset ovat keskenään ristiriidassa. Ongelma ei välttämättä poistu, vaikka yksilö löytää mielekkään tulkintakehyksen ja viiteryhmän esimerkiksi rajatiedon piiristä. Kirjoittajat saattavat kokea myös luonnontieteellisen diskurssin omakseen ja toivoa, että se kehittyisi vastaamaan rajatiedon osoittamiin haasteisiin.

Kirjoittajista merkittävä osa on akateemisesti koulutettuja. Useat korostavat suhtautuvansa kokemuksiin analyyttisesti ja kriittisesti, joskin kritiikin kohteet ja perusteet vaihtelevat. Lähdekritiikin kohteena voi olla tapahtuman konkreettisuus tai toisaalta alttius kokea sitä, mitä toivoo:

[...] olen yleensä hyvin valikoiva siinä, mitä lasken yliluonnolliseksi kokemukseksi, enkä ole koskaan ottanut mukaan pelkkiä "tuntemuksia" tai "aavistuksia", vaan vain konkreettisia tapahtumia. (Teresa, MT14/1.)

Olin [meediotilaisuudessa] mukana avoimin mielin, mutta samalla kuuntelin tarkasti ja kriittisesti. Tiedän kokemuksesta, että kun ihminen haluaa uskoa johonkin, hän näkee helposti tosiasiat sen mukaisesti. (Patrik, MT44/1.)

Iältään kirjoittajat ovat pääosin keski-iän ylittäneitä. Ikäjakaumaa ei selitä yksin se, että nuorempi polvi keskustelisi kokemuksistaan internetissä. Myös kirjoittajissamme on aktiivisia netin käyttäjiä. Toinen syy voi olla, että vanhemman polven maailmankuvaan kuuluu vielä verrattain yhtenäinen, valtainstituutioita kunnioittava julkinen keskustelu. Sukupolvi, jonka sosiaalista todellisuutta on leimannut huoli omasta ja koko perheen maineesta muiden silmissä, kokee valtakulttuurista poikkeavat kokemukset herkemmin ongelmallisiksi. Yksi kirjoittajista kiteyttää asian näin:

Olen joutunut koko elämäni pitämään nämä omituisuuteni omana tietonani, koska en ole halunnut joutua "hoitoon". Vasta nyt, kun olen jo seniorikansalainen uskallan puhuakin asiasta, kun työura on takana ja lapset selvinneet hyvin maailmalle. (Maire, MT6/1.)

Stigma, häpeäleima, on kokemus, johon useat kirjoittajat viittaavat. Monet kertovat saaneensa "hullun paperit" tai jonkin psykiatrisen diagnoosin jos ovat kertoneet kokemuksistaan terveydenhuollossa. Elämä stigman kanssa on voinut jatkua pitkään, joidenkin kertomuksissa elämän mittaisena.

\section{KUMMAN TULKITSEMISEN TAPOJA}

Valtaosa kertomuksista sisältää koetun tulkintoja ja pohdintoja. Kertomukset haastavat erilaisiin tulkintoihin. Kokijan kannalta tulkinnan ei tarvitse selittää koko maailmaa, vaan sen on oltava riittävä, jotta sen kanssa voi rauhassa nukkua yönsä. Tulkintakehyksen valinta kertoo siitä, millaiseen ajattelutapaan kokija haluaa identifioida itsensä.

Luonnontieteisiin luottava kokija pyrkii integroimaan myös kummat kokemukset tieteeseen. Selittämättömät ilmiöt voisivat tosiasiassa olla luonnollisia, vaikka 
aikamme tiede ei vielä ymmärrä niitä. Selitystä odotetaan muun muassa kvanttifysiikasta (Ilona, MT16). Luonnontieteiden epäillään myös harhautuneen luonnon ääreltä: "Kaikki mitä maailmassa tapahtuu, on luonnollista. Eri asia on se, kykeneekö teknokraattinen tiedeyhteisö puhuttelemaan asiaa luonnollisen kautta." (Henrik, MT19.) Monet ovat kokeneet dialogin luonnontieteiden kanssa yksipuoliseksi ja vähätteleväksi. Tuonpuoleiseen ja hengellisyyteen liittyvien kokemusten tieteellinen todistaminen voidaan kokea mahdottomaksi, koska "tieteelle vieraat tapahtumat voidaan yleensä helposti selittää sattumiksi, psyyken sisäisiksi tapahtumiksi tai lääkinnästä johtuviksi." (Pauli, MT30/2.)

Kristinusko on toinen legitiimiksi koettu selitysmalli. Luterilaisessa teologiassa yliluonnolliset ilmiöt voivat olla vain joko Jumalasta tai Saatanasta. Muussa tapauksessa ne ovat sielullisia eli kokijan kuvittelemia. Teologialla on kuitenkin varsin vähän vaikutusta kansanomaiseen uskonnollisuuteen. Käytännössä on täysin mahdollista sitoa enneunet, aavistukset, ruumiista irtautumiset, vainaja- ja enkelikokemukset sekä esoterian ja mystiikan harrastus kristilliseen kehykseen. (esim. Birgitta, MT61/2; Joonas, MT78/1.) Elämykset voivat vahvistaa kristillistä vakaumusta tai johtaa kokijan sen äärelle. Kokijat säilyttävät kuitenkin vapauden tulkita sitä omalla tavallaan:

Olin ateisti ennen kuin nämä kokemukset varsinaisesti isommalla määrällä alkoivat n 10 vuotta sitten. Niiden jälkeen olen pikkuhiljaa löytänyt maailmankatsomuksen, joka muistuttaa yllättävästi kristinuskoa, mutta ehkä hyvin erilailla, yliluonnollisesti tulkittuna, kuin mitä sitä yleensä opetetaan. (Teresa, MT14/1.)

Kirkon ja tieteen legitimoimien tulkintamallien ohella kokemuksia selitetään mielekkäiksi perhetradition voimalla tai tutustumalla vaihtoehtoisiin henkisiin suuntauksiin. Perhetraditio merkitsee tässä ensinnäkin sitä, että kokemukset tuonpuoleisesta todellisuudesta on koettu kotona luonnollisiksi:

Meidän perheessämme on suhtauduttu tuonpuoleiseen varsin luonnollisesti, kiitos äitini, ja minulla ja sisaruksillani on erilaisia kokemuksia. Minun elämässäni on myös edellinen elämäni ollut läsnä. (Ilona, MT16/1.)

Toiseksi se voi merkitä vainajaelämysten kokemista sukuyhteyden positiiviseksi jatkumoksi. Silloin nimenomaan kuolleet perheenjäsenet toimivat neuvojina ja opastajina kokijan elämässä.

Näen usein unta kuolleista omaisista ja he viestivät unissa asioita, jotka sitten käyvät toteen. Myöskin näillä kuolleilla omaisillani (isä, veli, sisko) oli ennakoivia näkyjä. [...] Veljeni oli kuollut v.1996 ja näin hänestä jatkuvasti unia ja hän neuvoi niissä aina miten tulisi minkäkin asian kanssa tehdä ja välillä kertoi tulevista asioista. (Helena, MT12/2.)

Vainajaelämykset ovat tyypillisimpiä vanhempien ja lasten välillä, ja tavallisia myös sisarusten ja puolisoiden välillä (Virtanen 1974, 24; Laiho, Kaunonen \& Aho 2014). Pitkäaikaiset ja kiinteät inmissuhteet tekevät läheisistä myös kuoleman jälkeen tärkeitä, ja tämä emotionaalinen side lisää vainajaelämysten mahdollisuutta (Bennett 1999, 29-31). Kokemukset vainajasta tai häneltä tulevista viesteistä ovat nykyaikaisen surututkimuksen mukaan yleisiä surevien keskuudessa (esim. 
Daggett 2005). Kun ajatus kuolleen läheisen hyvästijätöstä tai suojelusta tuntuu intuitiivisesti oikealta, lohdullinen kokemus itsessään voi olla tärkeämpi asia kuin kysymys, miten se oli mahdollista.

Vaihtoehtoisiin henkisiin suuntauksiin kuten spiritualismiin, enkelioppiin, teosofiaan tai ruusuristiläisyyteen kirjoittajat ovat tutustuneet tavallisesti kirjojen ja kurssien välityksellä tai esimerkiksi Suomen Spiritualistisen Seuran meediotilaisuuksissa. Kirjeaineistossamme edelleen näkyvä tieteen ja kristinuskon vahva auktoriteetti sopii yhteen vastaajien ikärakenteen kanssa. Muutos on tutkimuksessa nähty sukupolvikysymyksenä. Uusi sukupolvi hylkää sitoutumisen perinteisiin auktoriteetteihin ja aiempien sukupolvien arvovalintoihin ja etsii omat reittinsä kohti totuutta ja henkistä kehitystä. (Partridge 2012, 113-116.) Traditiot ovat murtuneet myös niiltä osin, ettei henkimaailma toimi enää kollektiivisen moraalin vaan yksilöllisen kehityksen suunnannäyttäjänä.

\section{TUTKIMUKSEN TAVOITTEITA JA HAASTEITA}

Nykyajan henkisyydessä arvostetaan omaa kokemusta ja intuitiota, ja muiden välittämään tietoon ja objektiivisuuteen suhtaudutaan jopa kriittisesti (esim. MacKian 2012). Tiede pyrkii objektiivisuuteen ja yleispäteviin kuvauksiin, kun taas uskonto ja henkisyys keskittyvät niihin henkilökohtaisiin kokemuksiin, toiveisiin ja tunteisiin, jotka ovat yksilölle todellisia. William James luonnehti tieteen pyrkimystä objektiivisuuteen vuonna 1902 seuraavasti: "Jos maailma kuvattaisiin jättämällä pois kaikki yksityisen inmisen kohtaloon kuuluvat erilaiset tunteet ja kaikki hengelliset asenteet [...] se olisi sama kuin annettaisiin ruokalista aterian asemesta. Uskonto ei tee sellaista erehdystä." (James 1981, 350.) Monet kirjoittajista ovat tietoisesti hakeutuneet dialogiin tieteen kanssa. Osa on kirjoittanut voidakseen vapautua kokemusten aikaansaamasta stigmasta. He toivovat, että tieteellinen tieto ja heidän kokemansa ilmiöt ja todellisuudet voisivat kohdata:

Toivon todella, että aivo- ja kognitiotutkimuksessa päästäisiin eteenpäin. En pidä näitä ns. yliluonnollisia asioita ollenkaan tuonpuoleisina. Joskus tullaan pitämään tätä aikaa todella primitiivisenä. Toivottavasti se aika on pian. Kiitos teille, että olette tutkimassa näitä aiheita. (Ilona, MT16/2.)

Olemme hankkeessamme ottaneet kirjoittajien meille välittämän viestin vakavasti. Tutkimuksessamme otamme lähtökohdaksemme inmisten kokemukset sellaisena kuin ne meille esitetään vailla luokittelua normaalin ja patologisen välillä (Canguilheim 1991). Tällainen tutkimusote avaa mahdollisuuden ihmismielen moninaisuuden tavoittamiseen. Ihmismielen ymmärtäminen sen kummia ominaisuuksiakaan kavahtamatta on askel kohti laajempia tieteidenvälisiä näkökulmia. Yhtenä haasteena on sellaisten käsitteistöjen ja näkökulmien luominen, joiden pohjalta mahdollisimman laaja yhteistyö olisi mahdollista. 
Kaarina Koski ja Marja-Liisa Honkasalo: Miten tutkia kummia kokemuksia?

\section{Tutkimusaineistot}

MT = Mieli ja toinen -tutkimushankkeen aineistot. Aineisto on projektin tutkijoiden hallussa. Kirjoittajien nimet on muutettu.

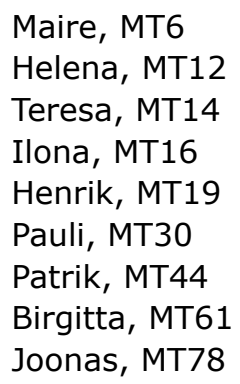

Kirjallisuus

Alles, Gregory D. 2006: The So-Called Cognitive Optimum and the Cost of Religious Concepts - Method \& Theory in the Study of Religion 18(4): 325-350.

Apo, Satu 1995: Naisen väki. Tutkimuksia suomalaisten kansanomaisesta kulttuurista ja ajattelusta. Helsinki: Hanki ja Jää.

Apo, Satu 1998: Suomalaisuuden stigmatisoinnin traditio - Alasuutari, Pertti \& Ruuska, Petri (toim.), Elävänä Euroopassa. Muuttuva suomalainen identiteetti. Tampere: Vastapaino. 83-129.

Aragon, Lorraine 2003: Missions and Omissions of the Supernatural: Indigenous Cosmologies and the Legitimisation of 'Religion' in Indonesia - Anthropological Forum: A Journal of Social Anthropology and Comparative Sociology 13(2): 131-140.

van Baaren, Theo 1972: Vi människor. De skriftlösa folkens religion och kultur. Stockholm: Läromedelsförlagen.

Barrett, Justin L. 2008: Coding and Quantifying Counterintuitiveness in Religious Concepts: Theoretical and Methodological Reflections - Method \& Theory in the Study of Religion 20(4): 308-338.

Bateson, Gregory 1972: Steps to an Ecology of Mind: Collected Essays in Anthropology, Psychiatry, Evolution and Epistemology. Chicago: University of Chicago Press.

Bennett, Gillian 1986: Narrative as Expository Discourse - Journal of American Folklore 99(394): 415-434.

Bennett, Gillian 1999: Alas, Poor Ghost! Traditions of Belief in Story and Discourse. Logan: Utah State University Press.

Berger, Peter ja Luckmann, Thomas 1994: Todellisuuden sosiaalinen rakentuminen. Tiedonsosiologinen tutkielma. Helsinki: Gaudeamus.

Bergson, Henri 1963: Henkinen tarmo. Suom. Ilmari Hollo. Porvoo: WSOY.

Boas, Franz 1955: The Mind of Primitive Man. New York: The Macmillan Company. [1938]

Bourdieu, Pierre 1990: The Logic of Practice. Stanford: Stanford University Press. 
Kaarina Koski ja Marja-Liisa Honkasalo: Miten tutkia kummia kokemuksia?

Boyer, Pascal 1994: The Naturalness of Religious Ideas. A Cognitive Theory of Religion. Berkeley, Los Angeles, London: University of California Press.

Boyer, Pascal 2001: Religion Explained. The Evolutionary Origins of Religious Thought. New York: Basic Books.

Canguilheim, Georges 1991: The Normal and the Pathological. New York: Zone Books.

Colman, Andrew M. (toim.) 2009: A Dictionary of Psychology (3rd ed.). [online.] Oxford \& New York: Oxford University Press. DOI < 10.1093/ acref/9780199534067.001.0001 > [23.3.2015.]

Csordas, Thomas 1990: Embodiment as a Paradigm for Anthropology. Ethos 18: 5-47.

Csordas, Thomas 1994: The Sacred Self. A Cultural Phenomenology of Charismatic Healing. Berkeley, Los Angeles and San Fransisco: University of California Press.

Daggett, Luann M. 2005: Continued Encounters: The Experience of After-Death Communication - Journal of Holistic Nursing 23(2): 191-207.

Durkheim, Emile 1964: The Elementary Forms of Religious Life. English translation by Joseph Swain. London: George Allen \& Unwin. [1915]

Enges, Pasi 2004: Uskon ja epäuskon traditiot. Leea Virtanen, parapsykologia ja tutkijan suhde yliluonnolliseen - Elore 11(1): ei sivunumeroita. [online]. < http://www.elore.fi/arkisto/1 04/eng104.html > [5.3.2015.]

Evans-Pritchard, Edward 1968: Witchcraft, Oracles and Magic among the Azande. Oxford: Clarendon. [1937]

Etymology online [online]. < http://www.etymonline.com/ >. [2.3.2015]

Favret-Saada, Jeanne 1980: Deadly Words. Witchcraft in the Bocage. Cambridge: Cambridge University Press.

Featherstone, Mike, Hepworth, Mike \& Turner, Bryan S. (eds.) 1991: The Body: social process and cultural theory. London: Sage.

Frazer, James 1993: The Golden Bough. Ware, Herts.: Wordsworth. [1921]

Freud, Sigmund 1981: The 'Uncanny'. - James Strachey (ed.), The Standard Edition of the Complete Psychological Works of Sigmund Freud, Volume XVII (1917-1919): An Infantile Neurosis and Other Works. London: The Hogarth Press and The Institute of Psycho-analysis. 217-256. [1919]

Garber, Daniel 2008: Soul and Mind: Life and Thought in The Seventeenth Century - Garber, Daniel \& Ayers, Michael (toim.), The Cambridge History of Seventeenth-Century Philosophy [online]. Cambridge: Cambridge Histories Online. 757-795. DOI < http://dx.doi.org/10.1017/CHOL9780521307635.002 $>$

Goffman, Erving 1963: Stigma: Notes on the Management of Spoiled Identity. Englewood Cliffs, N.J.: Prentice-Hall.

Granberg, Gunnar 1935: Skogsrået i yngre nordisk folktradition. Uppsala, A-b: Lundequistska bokhandeln i distribution.

Greenfield, Sidney 2003: Can Supernaturals Really Heal? A View of Science That Shows How They Might - Anthropological Forum: A Journal of Social Anthropology and Comparative Sociology 13(2): 151-158.

Greenwood, Susan 2000: Magic, Witchcraft and the Otherworld: An Anthropology. Oxford \& New York: Berg. 
Kaarina Koski ja Marja-Liisa Honkasalo: Miten tutkia kummia kokemuksia?

Greenwood, Susan 2005: The Nature of Magic. An Anthropology of Consciousness. Oxford \& New York: Berg.

Gregory, Richard L. 2004: Paranormal - Gregory, Richard L. (toim.), The Oxford Companion to the Mind [online]. Oxford \& New York: Oxford University Press. DOI < 10.1093/acref/9780198662242.001.0001 > [23.3.2015.]

Guthrie, Stewart 2002: Animal Animism: Evolutionary Roots of Religious Cognition - Pyysiäinen, Ilkka \& Anttonen, Veikko (eds.), Current Approaches in the Cognitive Science of Religion. New York: Continuum. 38-67.

Haavio, Martti 1942: Suomalaiset kodinhaltiat. Porvoo: WSOY.

Holbraad, Martin 2007 (eds.): Thinking through things. Theorising Artefacts Ethnographically. London: Routledge.

Honkasalo, Marja-Liisa 1998: Space and Embodied Experience: Rethinking the Body in Pain - Body \& Society 4(2): 35-57.

Honko, Lauri 1962: Geisterglaube in Ingermanland. Helsinki: Suomalainen Tiedeakatemia.

Honko, Lauri 1980: Miten luoda terminologia haltijaperinteen tutkimukselle? Lehtipuro, Outi (toim.), Perinteentutkimuksen perusteita. WSOY: Porvoo. 77-129.

Hovi, Tuija 2007: Usko ja kerronta. Arkitodellisuuden narratiivinen rakentuminen uskonliikkeessä. Turku: Turun yliopisto.

Howes, David 2009: Introduction: The Revolving Sensorium - Howes, David (ed.), The Sixth Sense Reader. Oxford \& New York: Berg. 1-52.

Hufford, David 1982: The Terror that Comes in the Night. An Experiencecentered Study of Supernatural Assault Traditions. Philadelphia: University of Pennsylvania Press.

Hufford, David 1995: Beings Without Bodies: An Experience-Centered Theory of the Belief in Spirits. - Barbara Walker (ed.): Out of the Ordinary. Folklore and the Supernatural. Logan: Utah State University Press. 11-45.

Hufford, David 2005: Sleep Paralysis as Spiritual Experience - Transcultural Psychiatry 42(1): 11-45.

James, William 1981: Uskonnollinen kokemus. Hämeenlinna: Karisto. [1902]

James, William 1986: Essays in Psychical Research. Cambridge: Harvard University Press.

Korkeila, Jyrki, Joutsenniemi, Kaisla, Oksanen, Jorma \& Sailas, Eila (toim.) 2011: Irti häpeäleimasta. Duodecim: Helsinki.

Koski, Kaarina 2011: Kuoleman voimat. Kirkonväki suomalaisessa uskomusperinteessä. Helsinki: SKS.

Kristeva, Julia 1980: Powers of Horror. An Essay in Abjection. New York: Columbia University Press.

Laiho, Suvi, Kaunonen, Marja \& Aho, Anna Liisa 2014: Yliluonnolliset ilmiöt lapsen kuoleman jälkeen - Thanatos 3(2): 45-60.

Latour, Bruno 2005: Emme koskaan ole olleet moderneja. Tampere: Vastapaino.

Lindeman, Marjaana \& Svedholm, Annika M. 2012: What's in a Term? Paranormal, Superstitious, Magical and Supernatural Beliefs by Any Other Name Would Mean the Same - Review of General Psychology 16(3): 241-255.

Luhrmann Tanya M. 1989: Persuasions of the Witch's Craft. Ritual Magic in Contemporary England. Cambridge: Harvard University Press. 
Kaarina Koski ja Marja-Liisa Honkasalo: Miten tutkia kummia kokemuksia?

[http://www.elore.fi/arkisto/1_15/koski_honkasalo.pdf]

MacKian, Sara 2012: Everyday spirituality: social and spatial enchantment. London: Palgrave.

Merleau-Ponty, Maurice 1962: Phenomenology of Perception. New York: Routledge and Kegan Paul.

Miller, Daniel (toim.) 2001: Home Possession: Material culture behind closed doors. Oxford: Berg.

Milton, J.R. 2008: Laws of Nature - Garber, Daniel \& Ayers, Michael (ed.), The Cambridge History of Seventeenth-Century Philosophy [online]. Cambridge: Cambridge Histories Online. 680-701. DOI < http://dx.doi.org/10.1017/ CHOL9780521307635.002 > [23.3.2015.]

Mitchell, Jon 2008: For Belief: Embodiment and Immanence in Catholism - Social Analysis 32: 79-94.

Oxford English Dictionary 2010 [online]. < http://www.oed.com/ > [2.3.2015].

Partridge, Christopher 2005: The Re-enchantment of the West: Volume 1: Alternative Spiritualities, Sacralization, Popular Culture and Occulture. Bloomsbury: T\&T Clark.

Partridge, Christopher 2012: Occulture is ordinary - Asprem, Egil \& Granholm, Kennet (ed.), Gnostica. Contemporary Esotericism. Durham: Acumen. 113-133.

Pyysiäinen, Ilkka 2008: Intuitionvastaisuus, essentialismi ja agenttius - Ketola, Kimmo \& Pyysiäinen, Ilkka \& Sjöblom, Tom (toim.), Uskonto ja ihmismieli: johdatus kognitiiviseen uskontotieteeseen. Helsinki: Gaudeamus. 31-50.

Raami, Asta 2013: Experiences on Developing Intuitive Thinking among Universitylevel Teachers - EKSIG 2013 conference, Knowing Inside Out - Nimkulrat, Nithikul \& Niedderer, Kristina \& Evans, Mark (eds.), Experiential Knowledge, Expertise and Connoisseurship, Design Research Society. Conference Proceedings. Loughborough University. 221-234.

Rydving, Håkan 2008: A Western Folk Category in Mind? - Temenos 44(1): 73-99.

Saler, Benson 1977: Supernatural as a Western Category - Ethos 5(1): 31-53.

Sarjala, Jukka 2014: Maailmaan uppoava subjekti. Riippuvuuden teema E.T.A. Hoffmannin Nukuttajassa - Lummaa, Karoliina \& Rojola, Lea (toim.), Posthumanismi. Turku: Eetos. 109-127.

Sartre, Jean-Paul 1992: Being and Nothingness. New York: Washington Square Press.

Sartre, Jean-Paul 2004: Imaginary. Phenomenological Psychology of Imagination. London and New York: Routledge.

Schutz, Alfred 2007: Sosiaalisen maailman merkityksekäs rakentuminen. Tampere: Vastapaino.

Sered, Susan 2003: Afterword: Lexicons of the Supernatural - Anthropological Forum: A Journal of Social Anthropology and Comparative Sociology 13(2): 213-218.

Siikala, Anna-Leena 1992: Suomalainen šamanismi: mielikuvien historiaa. Helsinki: SKS.

Skultans, Vieda 2001: Theorizing Latvian Lives - Journal of The Royal Anthropological Institute 3: 761-780.

Society for Psychical Research. [online] < http://www.spr.ac.uk/ >. [2.3.2015].

Sperber, Dan 1996: Explaining Culture. A Naturalistic Approach. Oxford: Blackwell Publishers. 
Stark, Laura 2006. Body, Society and the Supernatural in Early Modern Rural Tradition. Folklore Fellows Communications 290. Helsinki: Academia Scientiarum Fennica.

Stark, Laura 2014. Magic and Witchcraft in Their Everyday Context: Childhood Memories from the Nineteenth-century Finnish Countryside. - Nordic Yearbook of Folklore 70: 125-146.

Stoller, Paul 1989: The Taste of Ethnographic Things: The Senses in Anthropology. Philadelphia: University of Pennsylvania Press.

Svedholm, Annika 2013: The Cognitive Basis of Paranormal, Superstitious, Magical, and Supernatural Beliefs: The Roles of Core Knowledge, Intuitive and Reflective Thinking, and Cognitive Inhibition. Helsinki: Institute of Behavioural Sciences, University of Helsinki.

Tambiah, Stanley Jeyaraja 1990: Magic, science, religion, and the scope of rationality. Cambridge: Cambridge University Press.

Tarkka, Lotte 1989: Karjalan kuvaus kansallisena retoriikkana. Ajatuksia karelianismin etnografisesta asetelmasta - Knuuttila, Seppo \& Laaksonen, Pekka (toim.), Runon ja rajan tiellä. Kalevalaseuran vuosikirja 68. Helsinki: SKS. 243-257.

Tarkka, Lotte 2005: Rajarahvaan laulu: tutkimus Vuokkiniemen kalevalamittaisesta runokulttuurista 1821-1921. Helsinki: SKS.

Taussig, Michael 1993: Mimesis and Alterity. A Particular History of the Senses. New York: Routledge.

Toombs, Kay 1992: The Meaning of Illness. Dordrecht: Kluwer.

Tucker, James 2002: New Age Religion and the Cult of the Self - Society 39(2): 46-51.

Turner, Victor 1967: The Forest of Symbols. Ithaca: Cornell University Press.

Turner, Bryan 1991: Recent Developments in the Theory of the Body. Featherstone, Mike \& Hepworth, Mike \& Turner, Bryan (eds), The Body in Social Theory. London: Sage. 1-35.

Virtanen, Leea 1974: Kun kello pysähtyi. Tavallisen suomalaisen yliluonnolliset kokemukset. Porvoo \& Helsinki: WSOY.

Virtanen, Leea 1990: "That Must Have Been ESP!" An Examination of Psychic Experiences. Bloomington and Indianapolis: Indiana University Press.

Waldenfels, Bernard 2001: Bruchlinien der Erfahrung. Frankfurt: Suhrkamp.

Waldenfels, Bernard 2011: Phenomenology of the Alien. Evanston: Northwestern University Press.

Walker, Barbara 1995: Introduction. - Walker, Barbara (ed.): Out of the Ordinary. Folklore and the Supernatural. Logan: Utah State University Press. 1-7.

Painamattomat LÄHTEeT

Outinen, Kati 2014: Olemattoman ruumiillistaminen - Esitelmä Kumma-verkoston tutkijaseminaarissa 13.5.2014.

Dosentti Kaarina Koski toimii folkloristiikan määräaikaisena yliopistonlehtorina Turun yliopistossa sekä tutkijatohtorina Mieli ja toinen -hankkeessa. Hän on tarkastellut tutkimuksissaan kerronnan ominaisuuksia 
sekä kuolemaan, yliluonnollisiin olentoihin ja luterilaiseen kirkkoon liittyviä uskomustraditioita.

Professori Marja-Liisa Honkasalon tutkimustyö on kohdistunut sairauden kulttuurisuuteen. Hän on kiinnostunut ruumiillisesta kokemuksesta kärsimyksen kontekstissa sekä ihmisten erilaisista toimista maailmassa pysyttelemiseksi. 
Kaarina Koski ja Marja-Liisa Honkasalo: Miten tutkia kummia kokemuksia?

[http://www.elore.fi/arkisto/1_15/koski_honkasalo.pdf]

国

Elore (ISSN 1456-3010), vol. 22 - 1/2015. Julkaisija: Suomen Kansantietouden Tutkijain Seura ry. 
Kaarina Koski ja Marja-Liisa Honkasalo: Miten tutkia kummia kokemuksia?

[http://www.elore.fi/arkisto/1_15/koski_honkasalo.pdf]

(19)

Elore (ISSN 1456-3010), vol. 22 - 1/2015. Julkaisija: Suomen Kansantietouden Tutkijain Seura ry. 
Kaarina Koski ja Marja-Liisa Honkasalo: Miten tutkia kummia kokemuksia?

[http://www.elore.fi/arkisto/1_15/koski_honkasalo.pdf]

国

Elore (ISSN 1456-3010), vol. 22 - 1/2015. Julkaisija: Suomen Kansantietouden Tutkijain Seura ry. 
Kaarina Koski ja Marja-Liisa Honkasalo: Miten tutkia kummia kokemuksia?

[http://www.elore.fi/arkisto/1_15/koski_honkasalo.pdf]

国

Elore (ISSN 1456-3010), vol. 22 - 1/2015. Julkaisija: Suomen Kansantietouden Tutkijain Seura ry. 
Kaarina Koski ja Marja-Liisa Honkasalo: Miten tutkia kummia kokemuksia?

[http://www.elore.fi/arkisto/1_15/koski_honkasalo.pdf]

国

Elore (ISSN 1456-3010), vol. 22 - 1/2015. Julkaisija: Suomen Kansantietouden Tutkijain Seura ry. 
Kaarina Koski ja Marja-Liisa Honkasalo: Miten tutkia kummia kokemuksia?

[http://www.elore.fi/arkisto/1_15/koski_honkasalo.pdf]

国

Elore (ISSN 1456-3010), vol. 22 - 1/2015. Julkaisija: Suomen Kansantietouden Tutkijain Seura ry. 
Kaarina Koski ja Marja-Liisa Honkasalo: Miten tutkia kummia kokemuksia?

[http://www.elore.fi/arkisto/1_15/koski_honkasalo.pdf]

国

Elore (ISSN 1456-3010), vol. 22 - 1/2015. Julkaisija: Suomen Kansantietouden Tutkijain Seura ry. 
Kaarina Koski ja Marja-Liisa Honkasalo: Miten tutkia kummia kokemuksia?

[http://www.elore.fi/arkisto/1_15/koski_honkasalo.pdf]

国

Elore (ISSN 1456-3010), vol. 22 - 1/2015. Julkaisija: Suomen Kansantietouden Tutkijain Seura ry. 
Kaarina Koski ja Marja-Liisa Honkasalo: Miten tutkia kummia kokemuksia?

[http://www.elore.fi/arkisto/1_15/koski_honkasalo.pdf]

国

Elore (ISSN 1456-3010), vol. 22 - 1/2015. Julkaisija: Suomen Kansantietouden Tutkijain Seura ry. 
Kaarina Koski ja Marja-Liisa Honkasalo: Miten tutkia kummia kokemuksia?

[http://www.elore.fi/arkisto/1_15/koski_honkasalo.pdf]

国

Elore (ISSN 1456-3010), vol. 22 - 1/2015. Julkaisija: Suomen Kansantietouden Tutkijain Seura ry. 
Kaarina Koski ja Marja-Liisa Honkasalo: Miten tutkia kummia kokemuksia?

[http://www.elore.fi/arkisto/1_15/koski_honkasalo.pdf]

国

Elore (ISSN 1456-3010), vol. 22 - 1/2015. Julkaisija: Suomen Kansantietouden Tutkijain Seura ry. 
Kaarina Koski ja Marja-Liisa Honkasalo: Miten tutkia kummia kokemuksia?

[http://www.elore.fi/arkisto/1_15/koski_honkasalo.pdf]

(19)

Elore (ISSN 1456-3010), vol. 22 - 1/2015. Julkaisija: Suomen Kansantietouden Tutkijain Seura ry. 